\title{
ARTICLE OPEN Methane emissions from groundwater pumping in the USA
}

\author{
J. T. Kulongoski ${ }^{1}$ and P. B. McMahon ${ }^{2}$
}

Atmospheric methane accumulation contributes to climate change, hence quantifying methane emissions is essential to assess and model the impacts. Here, we estimate methane emissions from groundwater pumping in the Los Angeles Basin (LAB), north-eastern Pennsylvania, and the Principal aquifers of the USA using the average concentrations of methane in groundwater and annual groundwater pumping volumes. High average methane concentrations, $44.1 \mathrm{mg} / \mathrm{L}$, and extensive groundwater pumping, $\sim 3.1 \times$ $10^{11} \mathrm{~L} / \mathrm{a}$ in the $L A B$, result in the annual emission of $\sim 2.9 \times 10^{-3} \mathrm{Tg}$ of microbial methane. Ethane emissions in the LAB were $3.5 \times$ $10^{-6} \mathrm{Tg} / \mathrm{a}$. Lower methane emissions estimated for NE Pennsylvania, $\sim 3.0 \times 10^{-6} \mathrm{Tg} / \mathrm{a}$, reflect lower methane concentrations and groundwater pumping, $0.7 \mathrm{mg} / \mathrm{L}$ and $4.27 \times 10^{9} \mathrm{~L} / \mathrm{a}$, respectively. Methane concentrations and groundwater withdrawals, $1.06 \times$ $10^{14} \mathrm{~L} / \mathrm{a}$, across the USA enabled the estimation of the total emissions of methane from Principal aquifers (92\% of total pumping) of $0.044 \mathrm{Tg} / \mathrm{a}$ in the year 2000, which represents a small percentage $(\sim 0.2 \%)$ of the total annual US methane emissions, but a previously unquantified flux in the global methane budget. Globally, groundwater-pumping methane emissions were estimated to be $0.53 \mathrm{Tg} / \mathrm{a}, 0.2 \%$ of global methane emissions, by adopting a global estimate for groundwater extraction, and an average methane concentration in older groundwater of $0.44 \mathrm{mg} / \mathrm{L}$.

npj Climate and Atmospheric Science (2019) 2:11 https://doi.org/10.1038/s41612-019-0068-6

\section{INTRODUCTION}

Methane, a reduced form of carbon, is a minor component of the atmosphere at 1840 parts per billion in the year 2016. Methane's atmospheric residence time is 12-17 years, and methane has a global warming potential of 25 over 100 years $\left(G P_{100}\right.$ of 25$)$, compared with carbon dioxide, which has a GWP ${ }_{100}$ of 1. ${ }^{1}$ From 2000 to 2006, atmospheric concentrations of methane remained relatively constant, however, from 2007 to 2013, atmospheric methane increased by more than 5\%, and in 2014 and 2015, concentrations increased by more than $10 \%,{ }^{2}$ and are approaching high greenhouse-gas scenarios, which could exacerbate climate change. Proposed drivers of methane emissions include growth in fossil fuel use, increased agricultural production, thawing arctic permafrost, increased precipitation and tropical flooding, and the decrease in hydroxyl radicals in the atmosphere. However, confirmation is difficult because of uncertainties in the global methane budget. Identification and quantification of previously unidentified sources of methane emissions is crucial for improving methane budget estimates, and modeling climate change. ${ }^{3}$

Methane gas is predominantly derived from organic matter and produced by either thermogenic or microbial processes. ${ }^{4}$ Thermogenic methane forms when organic matter is buried and heated, usually at considerable depths over long periods of time, and includes methane associated with coal, gas, and oil formations. Microbial methane formation follows two pathways: via acetate fermentation or $\mathrm{CO}_{2}$ reduction, typically at shallower depths, by the actions of methanogenic organisms, members of the domain Archaea, on organic matter in anoxic environments, such as wetlands, landfills, and some aquifer sediments and coal deposits. Both thermogenic and microbial methane accumulate in groundwater as a result of generation, migration, and accumulation, ${ }^{5-10}$ with measured concentrations as high as $150 \mathrm{mg} / \mathrm{L}$ in the LAB. ${ }^{7}$
Groundwater pumping and the subsequent release of dissolved methane is potentially a significant source of methane emissions that has not been quantified in the global methane budget, ${ }^{11}$ although methane emissions from groundwater in the UK have been estimated at $2.2 \times 10^{-6} \mathrm{Tg} / \mathrm{a}$, about $0.05 \%$ of total UK methane emissions. ${ }^{12}$ Methane and other dissolved gases are typically removed from drinking-water distribution networks by several methods, included vented well caps, cascade, cone, and spray aerators, air stripping, or discharge into open or vented tanks.

While studying the sources and formation pathways for methane in $L A B$ groundwater, ${ }^{7}$ the implications for the high methane concentrations and large volumes of annual groundwater pumping led to the estimation of methane emissions from the $L A B$, and a comparison with the Marcellus shale region of NE Pennsylvania. Further compilation of recent groundwater methane data, ${ }^{13}$ and annual groundwater pumping, ${ }^{14}$ enabled estimation of methane emissions from groundwater pumping in the Principal aquifers of the USA (Fig. 1).

\section{RESULTS}

We estimate the emission of methane from the $L A B$ at $2.9 \times 10^{-3}$ $\mathrm{Tg} / \mathrm{a}$, by multiplying the annual groundwater abstraction for each aquifer (unit) by the average (arithmetic) methane concentration of each unit (Table 1), similar to approaches estimating the flux of nitrous oxide $\mathrm{e}^{15,16}$ and methane from groundwater pumping. ${ }^{12}$ According to the Water Replenishment District of Southern California, in the year $2000,3.1 \times 10^{11} \mathrm{~L}$ of groundwater was pumped for municipal and industrial supply in the LAB. ${ }^{17,18}$ The distribution of pumping varies by chronostratigraphic unit (Table 2), with most groundwater pumped from the Pacific A, Pacific, and Harbor units. ${ }^{17,19}$ However, emissions from the

${ }^{1}$ U.S. Geological Survey, California Water Science Center, San Diego, CA 92101, USA and ${ }^{2}$ U.S. Geological Survey, Colorado Water Science Center, Denver, CO 80225, USA Correspondence: J. T. Kulongoski (kulongos@usgs.gov)

Received: 11 July 2018 Accepted: 26 February 2019

Published online: 25 March 2019 


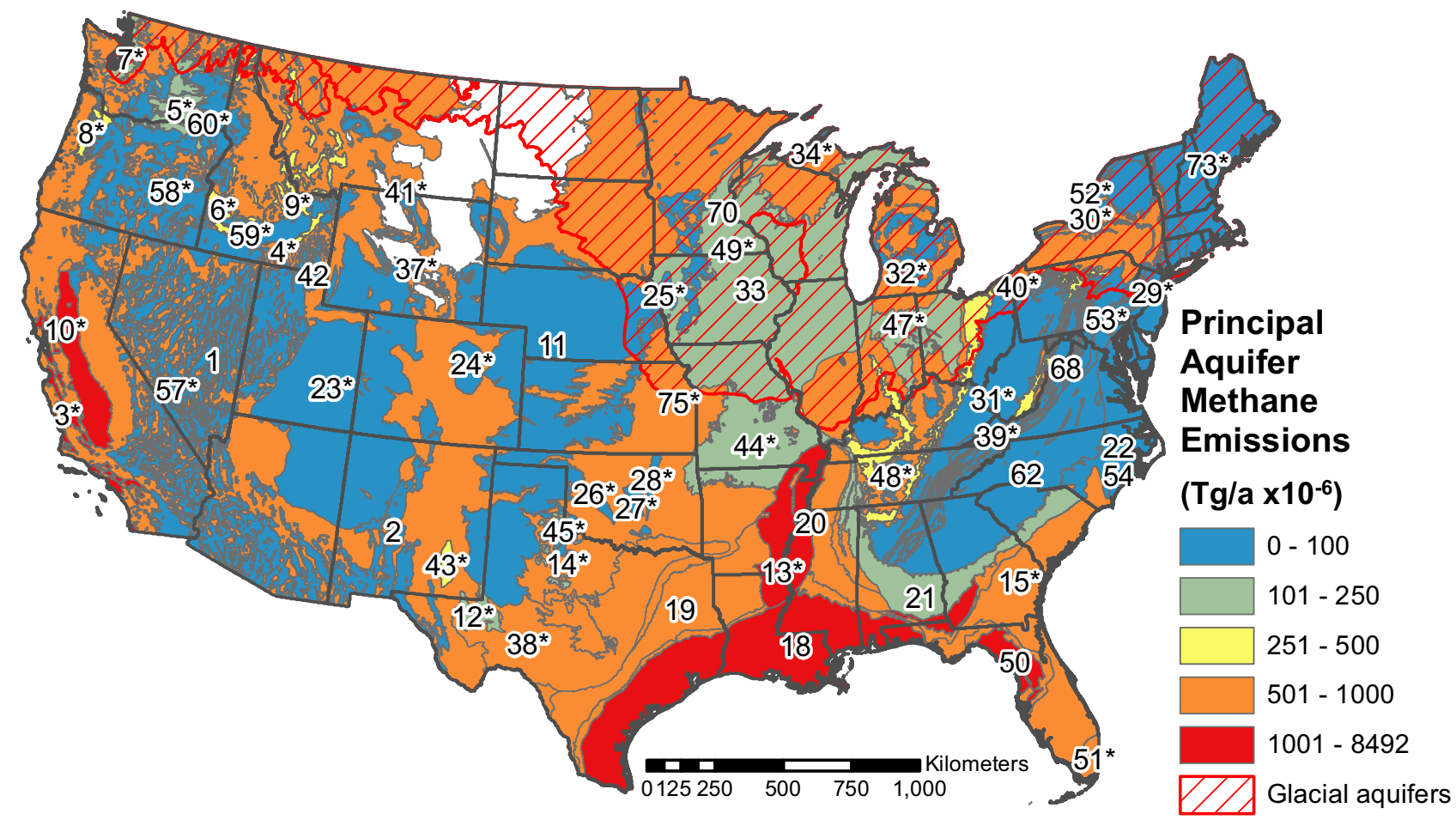

Fig. 1 Methane emissions resulting from pumping groundwater in the Principal aquifers of the USA. See Table 5 for aquifer names and values. Not shown but included in the total US groundwater pumping methane emissions are Alaska, Puerto Rico, Hawaii, and US Virgin Islands; *extrapolated estimate

Dominguez, Mesa, and Pacific units could not be estimated, since no wells in these units were sampled, and emission estimates were based only on the sampled units. This approach assumes all methane is completely degassed during pumping, treatment, and distribution of groundwater. ${ }^{12,15,16}$ Total ethane emissions also were calculated similarly, $3.5 \times 10^{-6} \mathrm{Tg} / \mathrm{a}$ from the $\mathrm{LAB}$ aquifer systems.

\section{DISCUSSION}

For comparison, groundwater-pumping methane emissions for the $L A B$, an area of $1088 \mathrm{~km}^{2}$, are $\sim 0.7 \%$ of methane emitted annually from all sources in the South Coast Air Basin (SoCAB), an area of $17,469 \mathrm{~km}^{2}$, which includes urbanized portions of Los Angeles, Orange, Riverside, and San Bernardino Counties, and $\sim 3 \%$ of the methane released from the Aliso Canyon storage facility leak in 2015-2016 (Table 2). The ethane released from groundwater in the $\mathrm{LAB}$ is only $\sim 0.02 \%$ of annual SoCAB emissions, and $\sim 0.05 \%$ the Aliso Canyon release. While a relatively brief event, the Aliso Canyon gas storage facility leak near Los Angeles from 2015 to 2016 released over $0.1 \mathrm{Tg}$ methane and $7.7 \times 10^{-3} \mathrm{Tg}$ ethane to the atmosphere. ${ }^{20,21}$ Annual emissions of methane since 2007 in the SoCAB have been $\sim 0.413 \pm 0.086 \mathrm{Tg} / \mathrm{a}$ methane and $\sim 0.023 \mathrm{Tg} / \mathrm{a}$ ethane. ${ }^{21,22}$ Methane emissions in the United States for various sectors including agriculture, energy, waste, industrial processes, land use change and forestry have been estimated as a total flux of $\sim 29.03 \mathrm{Tg}$ of methane ${ }^{23}$ in the year 2000. Global emissions of methane are estimated at $\sim 275 \mathrm{Tg} /$ a of methane in $2010 .^{2}$

High methane concentrations, those in excess of values expected from water equilibrating with the atmospheric $(\sim 5 \times$ $10^{-5} \mathrm{mg} / \mathrm{L}$ at $1 \mathrm{~atm}$ and $10^{\circ} \mathrm{C}$ ), have been identified in many aquifers in hydrocarbon-producing regions across the USA and the world e.g. ${ }^{24-27}$ The average methane concentration of 1701 Pennsylvania groundwater samples overlying the Marcellus is $0.7 \mathrm{mg} / \mathrm{L}^{24}$ (less than detection-level values were assigned a value of zero, so this is a lower limit), the average concentration in aquifers overlying the Bakken shale is $2.8 \mathrm{mg} / \mathrm{L},{ }^{28}$ Eagle Ford shale is $1.3 \mathrm{mg} / \mathrm{L}$, Haynesville-Bossier shale is $2.6 \mathrm{mg} / \mathrm{L}$, Fayetteville shale is $1.9 \mathrm{mg} / \mathrm{L},{ }^{29}$ and in the entire UK is $0.045 \mathrm{mg} / \mathrm{L}$. ${ }^{30}$ The annual emissions of methane from the Pennsylvania groundwater overlying the Marcellus is $3.0 \times 10^{-6} \mathrm{Tg} / \mathrm{a}$, calculated using the average methane concentration $(0.7 \mathrm{mg} / \mathrm{L})$, and average annual withdrawal of $4.27 \times 10^{9} \mathrm{~L} / \mathrm{a}$ in Susquehanna County https://water. usgs.gov/watuse/data/2005/index.html suggesting a relatively small contribution to the total US methane emissions from this area (Table 3). Future work is needed to quantify the withdrawal of groundwater in the Bakken, Eagle Ford, Haynesville-Bossier, and Fayetteville regions to calculate additional emissions of methane to the atmosphere from groundwater withdrawn from these hydrocarbon-producing regions. It should be noted that this is a coarse estimation of emissions from pumped groundwater to the atmosphere, based on a limited number of groundwater locations and samples that may be biased toward high-methane groundwater. Additional randomized sampling is needed for improved estimates.

To constrain emissions of methane from groundwater pumping across the USA, the average methane concentrations in 15 Principal aquifers were calculated using data from 833 sampled groundwater wells; $^{13}$ less than reporting-level values were assigned a value of zero (Table 4). By treating values reported as less than the detection level as zero, the methane emissions calculated in this work are a minimum estimate. If the nondetections are assigned the value of one-half the detection level, the average methane concentrations in nine of fifteen aquifers, and the average of all samples, were the same as using a value of zero, while the other six aquifers were within $45 \%$. Public-supply wells were selected for sampling using a randomized spatially distributed grid-cell network to provide statistical representation for the public-supply aquifers. ${ }^{13}$ The methane data are representative of methane emissions associated with pumping from public-supply wells. The 15 Principal aquifers sampled ${ }^{13}$ correspond to 15 of the 66 Principal aquifers identified by Maupin and 
Table 1. Los Angeles Basin groundwater sample ID, well depth, perforation intervals, dissolved methane concentration, and model layer and chronostratigraphic unit

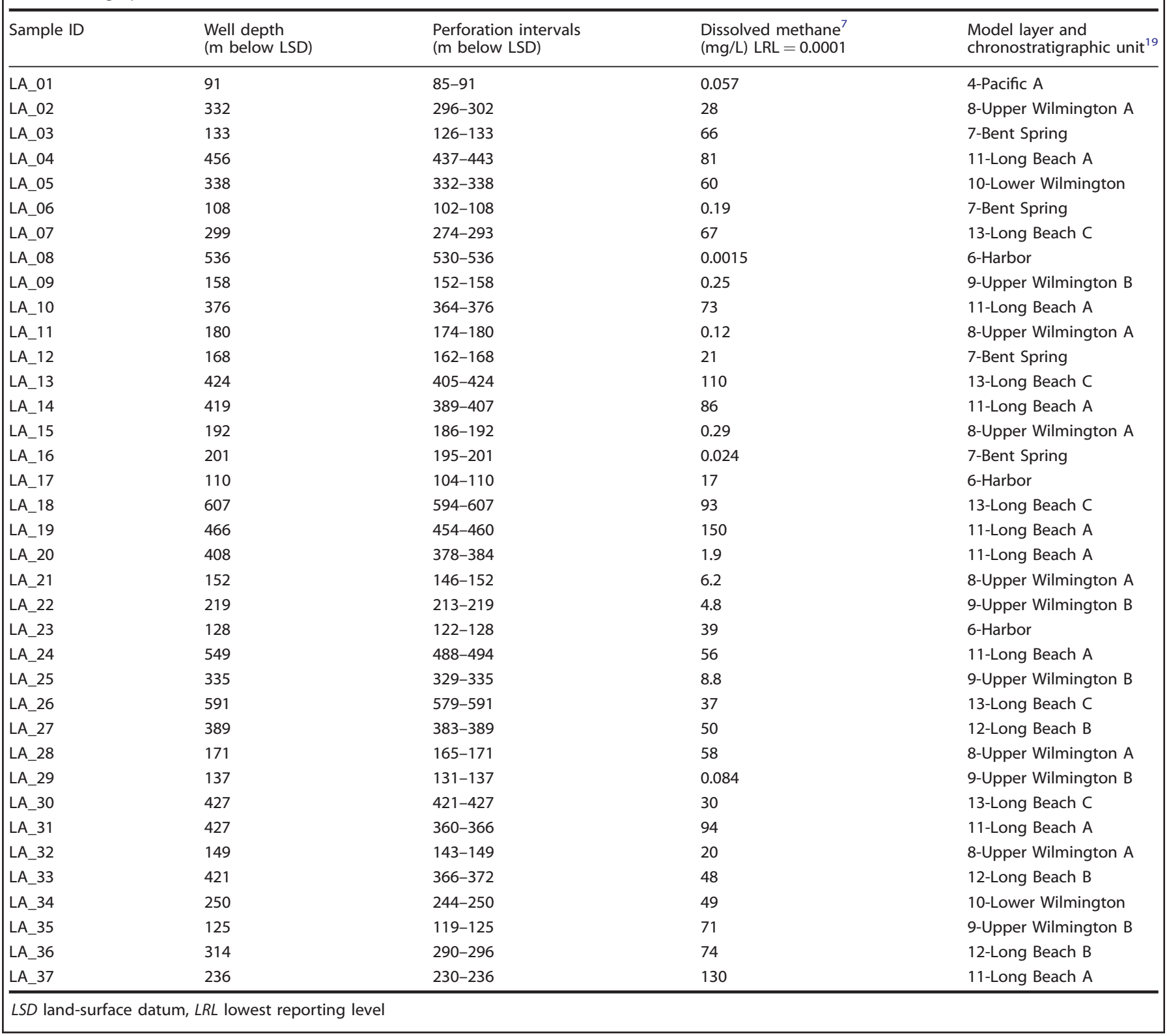

Barber, ${ }^{14}$ who estimated groundwater withdrawals from the Principal aquifers of the USA. Total withdrawals from the Principal aquifers in the USA was $1.06 \times 10^{14} \mathrm{~L} / \mathrm{a}$ in $2000 .^{14}$

Annual methane emissions (Table 4) calculated for the 15 Principal aquifers discussed in McMahon et al. ${ }^{13}$, represent only $\sim 50 \%$ of the groundwater withdrawal in the USA. To calculate the methane emissions from all 66 Principal aquifers, they were grouped into six Principal aquifer systems by lithology: carbonate rock, crystalline rock, sandstone, semi-consolidated sand, glacial unconsolidated sand and gravel, and nonglacial unconsolidated sand and gravel aquifer systems. Withdrawals from aquifers not included in one of the 66 Principal aquifers were reported in an "other" aquifers group. ${ }^{14}$ The emissions from all six Principal aquifer systems were calculated by assuming that the average methane concentration for the aquifers with data in a Principal aquifer system were representative of other aquifers in the same lithologic group without data. The methane concentration for each of the six aquifer systems were assumed to be the average of the aquifers within it. In some cases, such as the Sandstone Principal Aquifer System, there was only one aquifer ${ }^{13}$ methane concentration to base the value on. The "other" aquifers group was assigned the average methane concentration for all Principal aquifers systems $(0.44 \mathrm{mg} / \mathrm{L})$.

The annual emissions from the six aquifer systems and "other" aquifers were $0.041 \mathrm{Tg} / \mathrm{a}$ (Table 4). Subtracting the $2.3 \times 10^{-6} \mathrm{Tg} / \mathrm{a}$ calculated from this method with the Maupin and Barber ${ }^{14}$ data for the LAB (included in the California Coastal Plain PAS), and adding the $2.9 \times 10^{-3} \mathrm{Tg} / \mathrm{a}$ estimated from this study for the $L A B$, total annual methane emissions from the Principal aquifers in the USA are $0.044 \mathrm{Tg} / \mathrm{a}$ (Table 4$)$, a small part $(\sim 0.2 \%)$ of the US total. However, groundwater-pumping methane emissions in the USA are similar to the emissions of methane from leaking oil and gas wells, ${ }^{31}$ or industrial processes (Table 3). Most of the groundwater methane in the USA is emitted from Semi-Consolidated Sand and Gravel Principal Aquifer Systems (Fig. 1). Better constraints on the methane concentrations and groundwater pumping in the three 
Table 2. Groundwater-pumping methane and ethane emissions from each chronostratigraphic unit in the Los Angeles Basin, including the annual volume of groundwater pumped from each unit and percent of total pumping for each unit, average methane concentration of each unit, average ethane concentration of each unit, annual methane emissions and annual ethane emissions from each unit

\begin{tabular}{|c|c|c|c|c|c|c|}
\hline $\begin{array}{l}\text { Model layer } \\
\text { andchronostratigraphic unit }{ }^{19}\end{array}$ & $\begin{array}{l}\text { Pumped } \\
\text { groundwater (L/a) } \\
\left(\times 10^{8}\right)\end{array}$ & $\begin{array}{l}\% \text { annual } \\
\text { pumping }\end{array}$ & $\begin{array}{l}\text { Average methane } \\
\text { concentration }(\mathrm{mg} / \mathrm{L})\end{array}$ & $\begin{array}{l}\text { Average ethane } \\
\text { concentration (mg/L) }\end{array}$ & $\begin{array}{l}\text { Methane } \\
\text { emissions } \\
\left(\times 10^{-6} \mathrm{Tg} / \mathrm{a}\right)\end{array}$ & $\begin{array}{l}\text { Ethane } \\
\text { emissions } \\
\left(\times 10^{-6} \mathrm{Tg} / \mathrm{a}\right)\end{array}$ \\
\hline 3-Mesa & 472 & 15.3 & nd & nd & nd & nd \\
\hline 4-Pacific A & 515 & 16.7 & 0.057 & nd & 2.9 & nd \\
\hline 5-Pacific & 707 & 22.9 & nd & nd & nd & nd \\
\hline 8-Upper Wilmington A & 218 & 7.1 & 18.8 & 0.0736 & 409 & 1.60 \\
\hline 9-Upper Wilmington B & 21 & 0.69 & 17.0 & 0.0037 & 36.2 & 0.008 \\
\hline 10-Lower Wilmington & 87 & 2.82 & 54.5 & 0.008 & 474 & 0.073 \\
\hline 11-Long Beach A & 0 & 0.01 & 84.0 & 0.0283 & 2.7 & 0.0009 \\
\hline 12-Long Beach B & 28 & 0.92 & 57.3 & 0.0122 & 162 & 0.034 \\
\hline South Coast Air Basin ${ }^{21}$ & na & na & na & na & 413,000 & 23,000 \\
\hline
\end{tabular}

nd no data, na not applicable

2014-2015 Aliso canyon leak data and South Coast Air basin data are presented for comparison

Table 3. Comparison of methane concentrations in groundwater in different study areas in the USA, annual groundwater withdrawal rates, and calculated annual methane emissions from groundwater pumping in oil and gas regions

\begin{tabular}{|c|c|c|c|c|c|}
\hline Study area & $\begin{array}{l}\text { Median methane } \\
\text { conc. (mg/L) }\end{array}$ & $\begin{array}{l}\text { Average methane } \\
\text { conc. (mg/L) }\end{array}$ & $\begin{array}{l}\text { Maximum mehtane } \\
\text { conc. (mg/L) }\end{array}$ & $\begin{array}{l}\text { Average withdrawal } \\
\text { rates (L/a) }\end{array}$ & $\begin{array}{l}\text { Calculated methane } \\
\text { emissions }\left(\times 10^{-6} \mathrm{Tg} / \mathrm{a}\right)\end{array}$ \\
\hline Los Angeles Basin, CA & 39 & 44.1 & 150 & $3.10 \times 10^{11}$ & 2882 \\
\hline Bakken $^{28}$ & 0.006 & 2.8 & 32 & nd & nd \\
\hline Denver-Julesburg, $\mathrm{CO}^{10}$ & $3.27 / 3.29$ & $0.01 / 0.08$ & 39 & nd & nd \\
\hline Eagle Ford ${ }^{29}$ & 0.003 & 1.3 & 24 & nd & nd \\
\hline Haynesville, $\mathrm{TX}^{9}$ & 0.053 & 4.5 & 33 & nd & nd \\
\hline Fayetteville $e^{29}$ & 0.017 & 1.9 & 28 & nd & nd \\
\hline $\mathrm{UK}^{12,29}$ & $<0.00005$ & 0.045 & 4.7 & nd & 2.2 \\
\hline USA-total in $2000^{23}$ & & & & & $29.03 \times 10^{6}$ \\
\hline USA-Energy & & & & & $12.9 \times 10^{6}$ \\
\hline USA-Agricultural & & & & & $9.41 \times 10^{6}$ \\
\hline
\end{tabular}

Principal aquifers, High Plains, Central Valley, and Mississippi River aquifers, which comprise $48 \%$ of the groundwater pumping in the USA, would greatly improve these estimates.

Uncertainties associated with the Tier $1^{11}$ emission estimates are at least $5 \%$, which reflects the measurement uncertainty for methane, but do not account for temporal methane variability, incomplete accounting of groundwater pumping, or the inaccurate estimation of an aquifer's average methane concentration. Some temporal variability of methane resulting from sampling protocols $^{32}$ or domestic wells ${ }^{33}$ may be dismissed in this study, as strict sampling protocols ${ }^{34,35}$ were used to sample public watersupply wells. However, significant variability in groundwater methane has been observed in samples (concentrations $<0.3 \mathrm{mg} / \mathrm{L}$ ) collected quarterly, ${ }^{30}$ and sample pairs, which varied by up to $67 \%,{ }^{10}$ representing significant uncertainty. Annual groundwater pumping uncertainties reflects either inaccurate reporting or missed pumping. Most large water purveyors are known and track pumping closely, so the uncertainty on reported pumping from public-supply wells is small, $<5 \%$. When aggregating pumping volumes, some small operators may fail to respond 


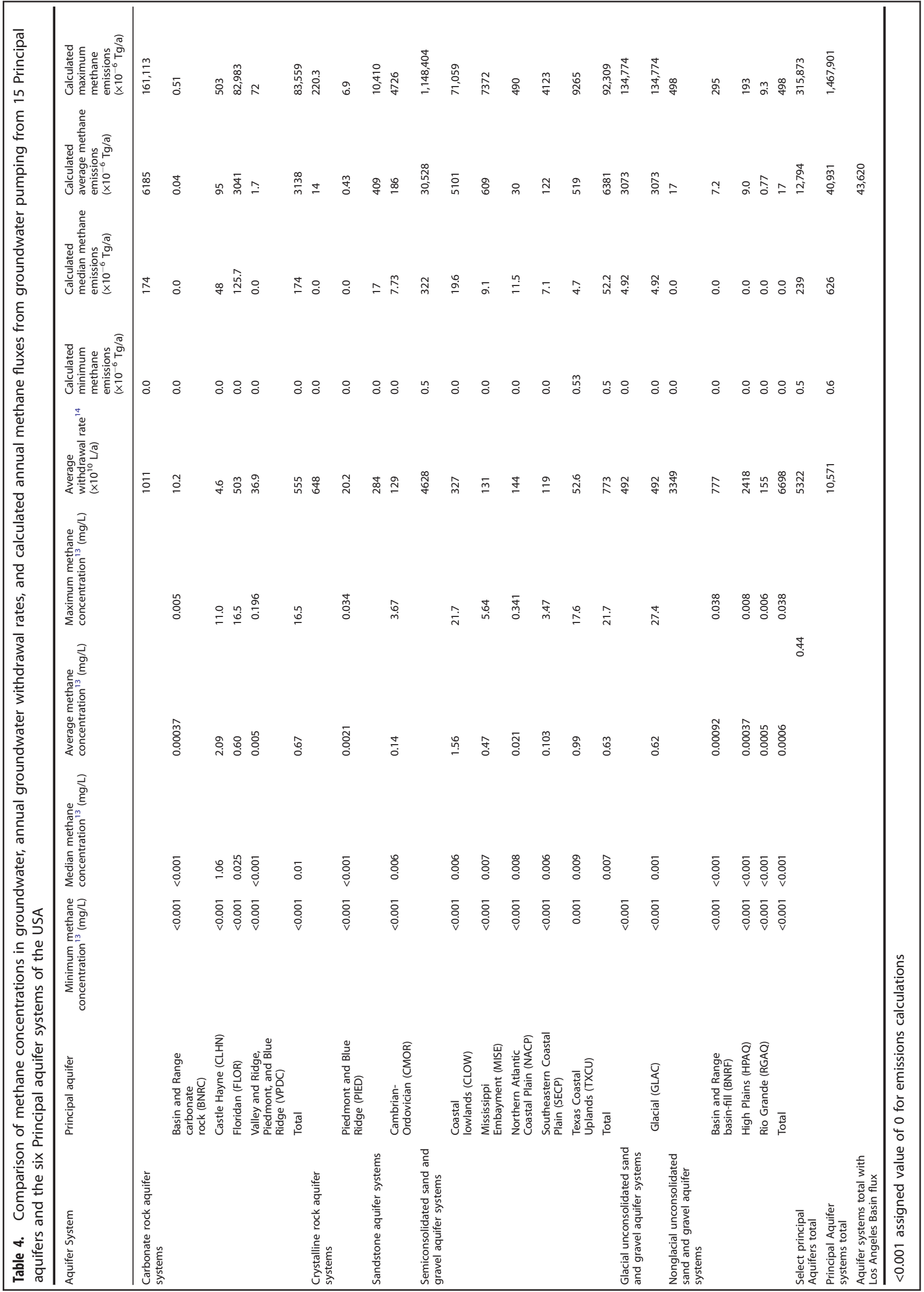


Table 5. Principal aquifer number, name, and methane emissions

\begin{tabular}{|c|c|c|c|}
\hline $\begin{array}{l}\text { Map } \\
\text { no. }\end{array}$ & Princial aquifer & $\begin{array}{l}\text { Average } \\
\text { withdrawal } \\
\text { rate }^{14}\left(\times 10^{10} \mathrm{~L} / \mathrm{a}\right)\end{array}$ & $\begin{array}{l}\text { Calculated } \\
\text { methane emissions } \\
\left(\mathrm{Tg} / \mathrm{a} \times 10^{-6}\right)\end{array}$ \\
\hline \multicolumn{4}{|c|}{ Semiconsolidated sand and gravel aquifer systems } \\
\hline 3 & $\begin{array}{l}\text { California Coastal Basin } \\
\text { aquifers }\end{array}$ & 475 & $2978^{*}$ \\
\hline 4 & $\begin{array}{l}\text { Pacific Northwest basin-fill } \\
\text { aquifers }\end{array}$ & 120 & $749 *$ \\
\hline 5 & $\begin{array}{l}\text { Columbia Plateau basin-fill } \\
\text { aquifers }\end{array}$ & 20 & $124^{*}$ \\
\hline 6 & $\begin{array}{l}\text { Snake River Plain basin-fill } \\
\text { aquifers }\end{array}$ & 65 & $408^{*}$ \\
\hline 7 & Puget Sound aquifer system & 36 & $225^{*}$ \\
\hline 8 & $\begin{array}{l}\text { Willamette Lowland basin-fill } \\
\text { aquifers }\end{array}$ & 58 & $363^{*}$ \\
\hline 9 & $\begin{array}{l}\text { Northern Rocky Mountains } \\
\text { Intermontane Basins aquifer } \\
\text { system }\end{array}$ & 52 & $327^{*}$ \\
\hline 10 & Central Valley aquifer system & 1355 & $8492^{*}$ \\
\hline 12 & $\begin{array}{l}\text { Pecos River Basin alluvial } \\
\text { aquifer }\end{array}$ & 17 & $107^{*}$ \\
\hline 13 & $\begin{array}{l}\text { Mississippi River Valley } \\
\text { alluvial aquifer }\end{array}$ & 1284 & $8042^{*}$ \\
\hline 14 & Seymour aquifer & 23 & $147^{*}$ \\
\hline 15 & Surficial aquifer system & 90 & $563^{*}$ \\
\hline $16 \wedge$ & $\begin{array}{l}\text { Unconsolidated-deposit } \\
\text { aquifers (Alaska) }\end{array}$ & 4.6 & $29 *$ \\
\hline $17 \wedge$ & $\begin{array}{l}\text { South Coast aquifer (Puerto } \\
\text { Rico) }\end{array}$ & 6.0 & $37^{*}$ \\
\hline 18 & $\begin{array}{l}\text { Coastal lowlands aquifer } \\
\text { system }\end{array}$ & 327 & 5101 \\
\hline 19 & $\begin{array}{l}\text { Texas coastal uplands } \\
\text { aquifer system }\end{array}$ & 53 & 519 \\
\hline 20 & $\begin{array}{l}\text { Mississippi embayment } \\
\text { aquifer system }\end{array}$ & 131 & 609 \\
\hline 21 & $\begin{array}{l}\text { Southeastern coastal plain } \\
\text { aquifer system }\end{array}$ & 119 & 122 \\
\hline 22 & $\begin{array}{l}\text { Northern Atlantic coastal } \\
\text { plain aquifer system }\end{array}$ & 144 & 30 \\
\hline 71 & Alluvial aquifers & 249 & $1558^{*}$ \\
\hline \multicolumn{4}{|c|}{ Glacial unconsolidated sand and gravel aquifer systems } \\
\hline 70 & Glacial aquifer system & 492 & 3073 \\
\hline \multicolumn{4}{|c|}{ Nonglacial unconsolidated sand and gravel aquifer systems } \\
\hline 1 & $\begin{array}{l}\text { Basin and Range basin-fill } \\
\text { aquifers }\end{array}$ & 777 & 7.2 \\
\hline 2 & Rio Grande aquifer system & 155 & 0.8 \\
\hline 11 & High Plains aquifer & 2418 & 9.0 \\
\hline \multicolumn{4}{|c|}{ Carbonate rock aquifer systems } \\
\hline 50 & Floridan aquifer system & 503 & 3041 \\
\hline 68 & $\begin{array}{l}\text { Valley and Ridge carbonate- } \\
\text { rock aquifers }\end{array}$ & 37 & 1.7 \\
\hline 42 & $\begin{array}{l}\text { Basin and Range carbonate- } \\
\text { rock aquifers }\end{array}$ & 10 & 0.04 \\
\hline 54 & Castle Hayne aquifer & 4.6 & 95 \\
\hline 53 & $\begin{array}{l}\text { Piedmont and Blue Ridge } \\
\text { carbonate-rock aquifers }\end{array}$ & 4.1 & $0.2^{*}$ \\
\hline 51 & Biscayne aquifer & 112 & $756^{*}$ \\
\hline 43 & Roswell Basin aquifer system & 53 & $359^{*}$ \\
\hline 47 & Silurian-Devonian aquifers & 34 & $229 *$ \\
\hline 44 & $\begin{array}{l}\text { Ozark Plateaus aquifer } \\
\text { system }\end{array}$ & 23 & $154^{*}$ \\
\hline $55^{\wedge}$ & $\begin{array}{l}\text { North Coast Limestone } \\
\text { aquifer system (Puerto Rico) }\end{array}$ & 8.1 & $55^{*}$ \\
\hline 52 & $\begin{array}{l}\text { New York and New England } \\
\text { carbonate-rock aquifers }\end{array}$ & 6.4 & $43^{*}$ \\
\hline 45 & Blaine aquifer & 6.1 & $41^{*}$ \\
\hline
\end{tabular}

\begin{tabular}{|c|c|c|c|}
\hline $\begin{array}{l}\text { Map } \\
\text { no. }\end{array}$ & Princial aquifer & $\begin{array}{l}\text { Average } \\
\text { withdrawal } \\
\text { rate }^{14}\left(\times 10^{10} \mathrm{~L} / \mathrm{a}\right)\end{array}$ & $\begin{array}{l}\text { Calculated } \\
\text { methane emissions } \\
\left(\mathrm{Tg} / \mathrm{a} \times 10^{-6}\right)\end{array}$ \\
\hline 49 & Upper carbonate aquifer & 1.3 & $8.9^{*}$ \\
\hline 48 & Ordovician aquifers & 0.8 & $5.4^{*}$ \\
\hline 46 & Arbuckle-Simpson aquifer & 0.6 & $3.9^{*}$ \\
\hline $56 \wedge$ & $\begin{array}{l}\text { Kingshill aquifer (Virgin } \\
\text { Islands) }\end{array}$ & 0.1 & $0.7^{*}$ \\
\hline \multicolumn{4}{|c|}{ Sandstone and carbonate rocks aquifer systems } \\
\hline 38 & $\begin{array}{l}\text { Edwards-Trinity aquifer } \\
\text { system }\end{array}$ & 102 & $689^{*}$ \\
\hline $72^{\wedge}$ & $\begin{array}{l}\text { Intermediate aquifer system } \\
\text { (Florida) }\end{array}$ & 49 & $330^{*}$ \\
\hline 40 & Mississippian aquifers & 40 & $266^{*}$ \\
\hline 39 & Valley and Ridge aquifers & 13 & $88^{*}$ \\
\hline 41 & Paleozoic aquifers & 2.5 & $17^{*}$ \\
\hline \multicolumn{4}{|c|}{ Crystalline rock aquifer systems } \\
\hline 59 & $\begin{array}{l}\text { Snake River Plain basaltic- } \\
\text { rock aquifers }\end{array}$ & 361 & $7.7^{*}$ \\
\hline 60 & $\begin{array}{l}\text { Columbia Plateau basaltic- } \\
\text { rock aquifers }\end{array}$ & 129 & $2.8^{*}$ \\
\hline 58 & $\begin{array}{l}\text { Pacific Northwest volcanic- } \\
\text { rock aquifers }\end{array}$ & 66 & $1.4^{*}$ \\
\hline $61^{\wedge}$ & $\begin{array}{l}\text { Volcanic-rock aquifers } \\
\text { (Hawaii) }\end{array}$ & 59 & $1.3^{*}$ \\
\hline 57 & $\begin{array}{l}\text { Southern Nevada volcanic- } \\
\text { rock aquifers }\end{array}$ & 0 & $0^{*}$ \\
\hline 62 & $\begin{array}{l}\text { Piedmont and Blue Ridge } \\
\text { crystalline-rock aquifers }\end{array}$ & 20 & 0.4 \\
\hline 73 & $\begin{array}{l}\text { New York and New England } \\
\text { crystalline-rock aquifers }\end{array}$ & 13 & $0.3^{*}$ \\
\hline \multicolumn{4}{|c|}{ Sandstone aquifer systems } \\
\hline 33 & $\begin{array}{l}\text { Cambrian-Ordovician } \\
\text { aquifer system }\end{array}$ & 129 & 186 \\
\hline 25 & Lower Cretaceous aquifers & 44 & $63^{*}$ \\
\hline $74 \wedge$ & $\begin{array}{l}\text { Northern Great Plains } \\
\text { aquifer system }\end{array}$ & 14 & $20^{*}$ \\
\hline 23 & Colorado Plateaus aquifers & 27 & $39^{*}$ \\
\hline 31 & Pennsylvanian aquifers & 18 & $26^{*}$ \\
\hline 29 & $\begin{array}{l}\text { Early Mesozoic basin } \\
\text { aquifers }\end{array}$ & 18 & $26^{*}$ \\
\hline 26 & Rush Springs aquifer & 7.8 & $11^{*}$ \\
\hline 30 & New York sandstone aquifers & 7.7 & $11^{*}$ \\
\hline 32 & Marshall aquifer & 7.4 & $11^{*}$ \\
\hline 24 & Denver Basin aquifer system & 5.0 & $7.2^{*}$ \\
\hline 27 & Central Oklahoma aquifer & 4.4 & $6.3^{*}$ \\
\hline 28 & Ada-Vamoosa aquifer & 0.6 & $0.8^{*}$ \\
\hline 34 & Jacobsville aquifer & 0.4 & $0.6^{*}$ \\
\hline 37 & Wyoming Tertiary aquifers & 0.2 & $0.3^{*}$ \\
\hline \multicolumn{4}{|c|}{ Other } \\
\hline 75 & Other aquifers & 160 & $705^{*}$ \\
\hline
\end{tabular}

or may be missed, such that their pumping was not included. These operators would represent a small portion of the groundwater pumping and as such, the uncertainty on unaccounted pumping is $\sim 5 \%$. In total, the uncertainty associated with annual groundwater pumping is estimated to be $\sim 10 \%$. The average methane concentrations estimated for each aquifer have the largest uncertainties, as calculations may be skewed depending on which wells were selected to sample. A randomized well selection process ${ }^{13,36}$ ensures that samples are representative of 
the concentrations in the aquifers being pumped. However, if studies do not collect enough samples to be representative, or their selection is not randomized, then the uncertainty could be up to $500 \%$ based on averaging sample concentrations in an aquifer. For the USGS Principal aquifer data, ${ }^{29}$ a randomization process was applied to available public-supply wells in the aquifers, and the uncertainty on the average methane concentrations in the public-supply aquifers was reduced to $\sim 25 \%$. The overall uncertainty on emissions estimates, based largely on possible temporal variability of methane is $\sim 80 \%$.

While small compared with total global emissions, ${ }^{11}$ methane emissions resulting from groundwater abstraction in the USA represent an important source to be quantified and should be included in the global methane budget. Emissions may be significant locally, where groundwater methane concentrations are high. Also, of local significance, methane, as a precursor to ozone formation, could represent an unaccounted for and potentially significant contribution to low-level ozone formation. More detailed analyses of correlations between methane concentrations and groundwater age, carbon system indicators, aquifer redox conditions, Eh potentials, as well as lithology and sediment age may help to better estimate methane occurrence and concentrations in groundwater. ${ }^{13,37}$ Within a given lithology group, methane concentrations are typically higher in younger sediments than in older sediments, ${ }^{13}$ and higher in older groundwater (pre 1950s) than recently recharged groundwater. ${ }^{7,13}$ Previous studies noted that sediment age can be important with respect to redox processes due to the preferential consumption of the most reactive components of sedimentary organic carbon by microbes over time. ${ }^{38-40}$ In support of this hypothesis, McMahon et al. ${ }^{13}$ found that for aquifers composed of similar lithologies, concentrations of methane, dissolved organic carbon, and ammonium were higher in the aquifers with younger sediments than in aquifers with older sediments.

If $78-99 \%$ of groundwater in the upper $2 \mathrm{~km}$ of the continental crust is older than 50 years, ${ }^{41,42}$ then groundwater methane may represent a significant source of methane, given increased rates of groundwater depletion $\left(1500 \mathrm{~km}^{3} / \mathrm{a}\right) .{ }^{43}$ If $80 \%$ of the 1500 $\mathrm{km}^{3} / \mathrm{a}$ extracted is old groundwater with elevated methane concentrations $(0.44 \mathrm{mg} / \mathrm{L}$ methane), then annual global groundwater-pumping methane emissions would be $\sim 0.53 \mathrm{Tg} /$ a, over three times the annual emissions from the metropolis of Los Angeles, California, but only $0.2 \%$ of global methane emissions. However, this estimate fails to capture the emissions of methane naturally/passively degassing from shallow methanogenic groundwater ${ }^{8}$ or from streams receiving methanogenic groundwater discharge, ${ }^{44}$ both of which could represent significant annual emissions. Further constraint of these processes is needed to better estimate extracted and natural methane groundwater emissions. Although expensive, given the number of groundwater wells, capturing the methane at the largest wells pumping groundwater with the highest methane concentrations could greatly reduce emissions. For example, in the Los Angeles Basin, capturing methane at 17 wells, which each pump more than $2.5 \times 10^{9} \mathrm{~L}$ annually, could reduce methane emissions by nearly a fifth.

\section{METHODS}

The $L A B$ is located within a northwest trending alluviated plain on the southern California coast, and contains deep sequences of petroliferous sediments and traps overlain by organic-rich marine and alluvial waterbearing sediments. ${ }^{19,45}$ Thirteen chronostratigraphic water-bearing units were identified using sequence stratigraphy to subdivide and link sedimentary deposits into unconformity-bound units. ${ }^{19}$ Wells were associated with chronostratigraphic unit based on well-screen depth and location (Table 1). Methane concentrations from 37 LAB groundwater samples ranged in concentration from $0.002 \mathrm{mg} / \mathrm{L}$ to $150 \mathrm{mg} / \mathrm{L}$ (Table 1), with an average value of $44.1 \mathrm{mg} / \mathrm{L}$. Sample selection for the LAB was not randomized, and as a result, LAB methane emissions have a larger uncertainty (500\%) than those of the Principal aquifers of the USA $(80 \%)$, and thus may overestimate methane emissions. While thermogenic methane was detected locally in the shallow subsurface in conjunction with some of the historic explosions that occurred in the $\mathrm{LAB}_{1}{ }^{46}$ the methane distribution and isotopic systematics, and groundwater age results indicate that most excess methane in LA groundwater originates from microbial production in anoxic or suboxic conditions in the shallow aquifer systems, rather than the migration of deeper thermogenic methane in the hydrocarbon-bearing formations associated with oil fields in the basin.?

Groundwater samples were collected in accordance with the protocols established by the USGS National Water-Quality Assessment (NAWQA) ${ }^{34}$ and the USGS National Field Manual ${ }^{35}$ after purging the equivalent of three casing-volumes from each well with a submersible pump. Samples were analyzed for a suite of inorganic, organic, and isotopic constituents; for a complete description of the sampling, analytical methods, quality assurance, and data. ${ }^{47}$ Samples for analysis for concentration and isotopic composition of hydrocarbon gases were collected by attaching sampling tubing to a hose bib and flushing groundwater through the tubing before the flow was partially restricted with a control valve. An evacuated pouch containing a bactericide capsule was attached to the tubing and filled with $600-700 \mathrm{~mL}$ of sample water. The hydrocarbon gas concentrations and isotopic values were measured using gas chromatography and isotope ratio mass spectrometry, respectively. Methane concentration measurement uncertainty is $\pm 0.0001 \mathrm{mg} / \mathrm{L}^{7}$, and the statistics on the methane measurements have been previously presented. ${ }^{7,13}$

\section{DATA AVAILABILITY}

All data used for calculations in this work are included in Tables 1-5. In addition, methane data for the $\operatorname{LAB}^{47}$ may be downloaded at: https://doi.org/10.3133/ ofr20161181. Methane data for the Principal aquifer ${ }^{13}$ may be downloaded at https://doi.org/10.5066/F7377766. Groundwater-pumping data for the Principal Aquifers of the USA ${ }^{14}$ are available for download at: https://pubs.usgs.gov/circ/ 2005/1279.

\section{ACKNOWLEDGEMENTS}

This work was funded by the U.S. Geological Survey National Water-Quality Assessment Program. Reviews by John Crawford and three anonymous reviewers were appreciated. The hydrocarbon gas concentrations and isotopic values were measured by Isotech Laboratories Inc., Champaign, IL. Any use of trade, firm, or product names is for descriptive purposes only and does not imply endorsement by the U.S. Government.

\section{AUTHOR CONTRIBUTIONS}

J.T.K.: conceived, researched, collected and analyzed data, and wrote this paper. P.B. M.: researched, collected data, provided guidance, and editing.

\section{ADDITIONAL INFORMATION}

Competing interests: The authors declare no competing interests.

Publisher's note: Springer Nature remains neutral with regard to jurisdictional claims in published maps and institutional affiliations.

\section{REFERENCES}

1. Intergovernmental Panel on Climate Change (IPCC). Climate Change 2013: The Physical Science Basis. Contribution of Working Group I to the Fifth Assessment Report of the Intergovernmental Panel on Climate Change. (eds T. F. Stocker, et al.) 1535 p., (Cambridge University Press: Cambridge, U.K., 2013).

2. Dlugokencky, E. J. 2016NOAA/ESRL, https://www.esrl.noaa.gov/gmd/ccgg/ trends_ch4/ (2016).

3. Saunois, M., Jackson, R. B., Bousquet, P., Poulter, B. \& Canadell, J. G. The growing role of methane in anthropogenic climate change. Environ. Res. Lett. 11, https:// doi.org/10.1088/1748-9326/11/12/120207 (2016).

4. Schoell, M. Genetic characterization of natural gases. Am. Assoc. Pet. Geol. Bull. 67, 2225-2238 (1983).

5. Darrah, T. H., Vengosh, A., Jackson, R. B., Warner, N. R. \& Poreda, R. J. Noble gases identify the mechanisms of fugitive gas contamination in drinking-water wells 
overlying the Marcellus and Barnett Shales. Proc Natl Acad. Sci. USA 111, 14076-14081 (2014).

6. Vengosh, A., Jackson, R. B., Warner, N., Darrah, T. H. \& Kondash, A. A critical review of the risks to water resources from unconventional shale gas development and hydraulic fracturing in the United States. Environ. Sci. Technol. 48, 8334-8348 (2014).

7. Kulongoski, J. T. et al. Origin of methane and sources of high concentrations in Los Angeles groundwater. J. Geophys Res-Biogeo 123, 818-831, https://doi.org/ 10.1002/2017JG004026 (2018).

8. Cahill, A. G. et al. Mobility and persistence of methane in groundwater in a controlled-release field experiment. Nat. Geosci. 10, 289-294 (2017).

9. Nicot, J. P. et al. Controls on methane occurrences in shallow aquifers overlying the Haynesville Shale gas field, East Texas. Groundwater 55, 443-454 (2017).

10. Sherwood, O. A. et al. Groundwater methane in relation to oil and gas development and shallow coal seams in the Denver-Julesburg Basin of Colorado. Proc. Natl Acad. Sci. 113, 8391-8396 (2016).

11. Intergovernmental Panel on Climate Change (IPCC). IPCC Guidelines for National Greenhouse Gas Inventories. (The National Greenhouse Gas Inventories Programme; The Institute for Global Environmental Strategies (IGES), (eds H.S. Eggleston, et al.) (Hayama, Japan, 2006).

12. Gooddy, D. C. \& Darling, W. G. The potential for methane emissions from groundwaters of the UK. Sci. Total Environ. 339, 117-126 (2005).

13. McMahon, P. B., Belitz, K., Barlow, J. R. B. \& Jurgens, B. C. Methane in aquifers used for public supply in the United States. Appl. Geochem. 84, 337-347 (2017).

14. Maupin, M. A. \& Barber, N. L. Estimated withdrawals from principal aquifers in the United States, 2000. U.S. Geological Survey Circular: 46 p. https://doi.org/10.3133/ cir1279 (Reston, 2005).

15. McMahon, P. B., Bruce, B. W., Becker, M. F., Pope, L. M. \& Dennehy, K. F. Occurrence of Nitrous oxide in the central High Plains Aquifer, 1999. Environ. Sci. Technol. 34, 4873-4877, https://doi.org/10.1021/es001233t/es001233t (2000).

16. Hiscock, K. M., Bateman, A. S., Mühlherr, I. H., Fukada, T. \& Dennis, P. F. Indirect emissions of nitrous oxide from regional aquifers in the United Kingdom. Environ. Sci. Technol. 37, 3507-3512 (2003).

17. Reichard, E. G. et al. Geohydrology, geochemistry, and ground-water simulationoptimization of the Central and West Coast basins, Los Angeles County, California. Report No. U.S. Geological Survey Water Resources Investigations Report 03-4065, 184 (Sacramento, 2003).

18. Water Replenishment Distrcit of Sountern California. http://www.wrd.org/ (2000).

19. Ponti, D. J., Wagner, B. J., Land, M. T. \& Landon, M. K. Characterization of potential transport pathways and implications for groundwater management near an anticline in the Central Basin area, Los Angeles County, California. U.S. Geological Survey Open-File Report 2014-1087: 75 p. (Reston, 2014).

20. Conley, S. et al. Methane emissions from the 2015 Aliso Canyon blowout in Los Angeles, CA. Science 351, 1317-1320 (2016).

21. California Air Resources Board. Determination of Total Methane Emissions from the Aliso Canyon Natural Gas Leak Incident. Report No. ARB Updated Emission Report October 21, 2016 Final (Sacramento, 2016).

22. Wunch, D. et al. Quantifying the loss of processed natural gas within California's South Coast Air Basin using long-term measurements of ethane and methane. Atmos. Chem. Phys. 16, 14091-14105 (2016).

23. Environmental Protection Agency. U.S. Greenhouse Gas Inventory Report: 1990-2014, https://www.epa.gov/ghgemissions/us-greenhouse-gas-inventoryreport-1990-2014 (2017).

24. Molofsky, L. J., Connor, J. A., Wylie, A. S., Wagner, T. \& Farhat, S. K. Evaluation of methane sources in groundwater in northeastern Pennsylvania. Ground Water 51, 333-349 (2013).

25. Osborn, S. G., Vengosh, A., Warner, N. R. \& Jackson, R. B. Methane contamination of drinking water accompanying gas-well drilling and hydraulic fracturing. Proc. Natl Acad. Sci. 108, 8172-8176 (2011).

26. Vidic, R. D., Brantley, S. L., Vandenbossche, J. M., Yoxtheimer, D. \& Abad, J. D. Impact of shale gas development on regional water quality. Science 340, https:// doi.org/10.1126/science.1235009 (2013).

27. Rivard, C. et al. An overview of Canadian shale gas production and environmental concerns. Int. J. Coal Geol. 126, 64-76 (2014).

28. McMahon, P. B., Caldwell, R. R., Galloway, J. M., Valder, J. F. \& Hunt, A. G. Quality and age of shallow groundwater in the Bakken Formation Production Area, Williston Basin, Montana and North Dakota. Groundwater 53, 81-94 (2015).
29. McMahon, P. B. et al. Methane and benzene in drinking-water wells overlying the Eagle Ford, Fayetteville, and Haynesville Shale Hydrocarbon Production Areas. Environ. Sci. Technol. 51, 6727-6734 (2017).

30. Bell, R. A. et al. A baseline survey of dissolved methane in aquifers of Great Britain. Sci. Total Environ. 601-602, 1803-1813 (2017).

31. Kang, M. et al. Identification and characterization of high methane-emitting abandoned oil and gas wells. Proc. Natl Acad. Sci. 113, 13636-13641 (2016).

32. Gorody, A. W. Factors affecting the variability of stray gas concentration and composition in groundwater. Environ. Geosci. 19, 17-31 (2012).

33. Smith, B., Becker, M. \& Siegel, D. Temporal variability of methane in domestic groundwater wells, northeastern Pennsylvania. Environ. Geosci. 23, 49-80 (2016).

34. Koterba, M. T., Wilde, F. D. \& Lapham, W. W. Ground-Water Data-Collection Protocols and Procedures for the National Water-Quality Assessment Program: Collection and Documentation of Water-Quality Samples and Related Data. U.S. Geological Survey Open-File Report 95-399. 113 (1995).

35. U.S. Geological Survey. National Field Manual for the Collection of Water-quality Data. Report No. U.S. Geological Survey Techniques of Water-Resources Investigations, book 9, chaps. A1-A9 (Reston, variously dated).

36. Belitz, K., Jurgens, B., Landon, M. K., Fram, M. S. \& Johnson, T. Estimation of aquifer scale proportion using equal area grids: Assessment of regional scale groundwater quality. Water Resour. Res. 46, https://doi.org/10.1029/2010WR009321 (2010).

37. Darling, W. G. \& Gooddy, D. C. The hydrogeochemistry of methane: evidence from English groundwaters. Chem. Geol. 229, 293-312 (2006).

38. Simpkins, W. W. \& Parkin, T. B. Hydrogeology and redox geochemistry of $\mathrm{CH} 4$ in a Late Wisconsinan Till and Loess Sequence in central lowa. Water Resour. Res. 29, 3643-3657 (1993).

39. Postma, D. et al. Groundwater arsenic concentrations in Vietnam controlled by sediment age. Nat. Geosci. 5, 656 (2012).

40. Erban, L. E., Gorelick, S. M. \& Fendorf, S. Arsenic in the multi-aquifer system of the Mekong Delta, Vietnam: analysis of large-scale spatial trends and controlling factors. Environ Sci Technol 48, 6081-6088 (2014).

41. Gleeson, T., Befus, K. M., Jasechko, S., Luijendijk, E. \& Cardenas, M. B. The global volume and distribution of modern groundwater. Nat. Geosci. 9, 161-167 (2016).

42. Aeschbach-Hertig, W. \& Gleeson, T. Regional strategies for the accelerating global problem of groundwater depletion. Nat. Geosci. 5, 853-861 (2012).

43. Döll, P. et al. Impact of water withdrawals from groundwater and surface water on continental water storage variations. J. Geodyn. 59-60, 143-156 (2012).

44. Heilweil, V. M., Solomon, D. K., Darrah, T. H., Gilmore, T. E. \& Genereux, D. P. Gastracer experiment for evaluating the fate of methane in a coastal plain stream: degassing versus in-stream oxidation. Environ. Sci. Technol. 50, 10504-10511 (2016).

45. Yerkes, R. F., McCulloh, T. H., Schoellhamer, J. E. \& Vedder, J. G. Geology of the Los Angeles Basin, California; An Introduction. Report No. U.S. Geological Survey Professional Paper 420-A, https://pubs.er.usgs.gov/publication/pp420A, 57 (1965).

46. Schoell, M., Jenden, P. D., Beeunas, M. A. \& Coleman, D. D. Isotope analyses of gases in gas field and gas storage operations. Society of Protroleum Engineers, Gas Technology Symposium, 337-344 (Alberta, CAN, 1993).

47. Dillon, D. B. et al. Data from Exploratory Sampling of Groundwater in Selected Oil and Gas Areas of Coastal Los Angeles County and Kern and Kings Counties in Southern San Joaquin Valley, 2014-15: California Oil, Gas, and Groundwater Project. Report No. 2016-1181, 34 (Reston, 2016).

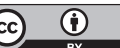

Open Access This article is licensed under a Creative Commons Attribution 4.0 International License, which permits use, sharing, adaptation, distribution and reproduction in any medium or format, as long as you give appropriate credit to the original author(s) and the source, provide a link to the Creative Commons license, and indicate if changes were made. The images or other third party material in this article are included in the article's Creative Commons license, unless indicated otherwise in a credit line to the material. If material is not included in the article's Creative Commons license and your intended use is not permitted by statutory regulation or exceeds the permitted use, you will need to obtain permission directly from the copyright holder. To view a copy of this license, visit http://creativecommons. org/licenses/by/4.0/.

This is a U.S. government work and not under copyright protection in the U.S.; foreign copyright protection may apply 2019 